\title{
Model Formulation to Estimate Manpower Demand for the Real-Estate Construction Projects in India
}

Anil L. Agarwal

NICMAR; 25/1, Balewadi, Pune (India)

anilagarwal@nicmar.ac.in

\section{B. L. Rajput}

NICMAR; 25/1, Balewadi, Pune (India)

babalurajput@nicmar.ac.in
Er. Satpute Mangesh A.

Gherzi Eastern Ltd., Mumbai (India)

satputema@yahoo.in
DOI 10.5592/otmcj.2013.2.1

Research Paper

\section{Keywords}

Manpower, Estimation, Real-estate, Planning, Regression Model
REAL ESTATE AS WELL AS INFRASTRUCTURE CONSTRUCTIONS ARE A PART OF THE DEVELOPMENT AND INDICATORS OF THE GROWTH OF THE ECONOMY. At any point of time huge amount of construction is carried out across pan India, with natural cycle of ups and downs in the quantum of work executed per annum. Construction requires large number of manpower in the categories of un-skilled, skilled and technical for planning, monitoring and execution of these projects. Manpower demand estimation is an essential component to facilitate manpower deployment. The construction output and manpower constants are found to be the most significant and sensitive factors determining the demand of construction manpower. In this paper efforts are made to formulate the model to assist in predicting manpower demand for effective deployment of the construction manpower from the contractor perspective. 


\section{INTRODUCTION}

Manpower requirement for the construction of real estate projects is different for the contracting agencies that do the construction of the project from the client who carry out the supervision of the construction. Being an important resource, proper planning of manpower on construction projects is a major concern for Project Managers. The project construction manpower planning is primarily concerned with estimating the worker's productivity, scheduling manpower employment and structuring it into workers teams and work groups, with a view to economically match manpower supply with the task requirements (K. K. Chitkara 2009). Estimating correct manpower requirements for each activity/work package is an important function of manpower planning team. Shortages in any typical category may result in time and cost overrun to construction projects with the reduction of overall productivity. However, the right combination of members to be included within a team is very difficult to specify and therefore a significant challenge exists in forming a good project team (G Coates et.al.2007). Manpower forecasting is needed to facilitate the construction programme and to prevent the damage to the company caused by attempts to undertake construction and when and where the resources are not available (James M.W.Wong et.al. 2004).

Traditionally, estimation of manpower required for each type of function is based upon previous experience of executing similar types of construction activities. Many handbooks, guideline and reference books are available which provides labour constants or productivity to arrive at manpower for various types of construction activities. Indian standard codes on recommendation for labour output constants for building works (IS 7272) are published zonewise by the Bureau of Indian Standards, New Delhi to standardised labour outputs. Even after these scientific and mathematical methods are available to calculate manpower for the construction project, still most of the construction contractors don't do manpower estimation for want of time. Construction contractors need approximate numbers only, as during construction period actual men deployment varies considerably. Thus, there is need to develop an effective method for manpower estimation at project level to give ballpark number of personals to facilitate manpower planning. Hence, this study is done with following objectives so as to meet the future manpower requirement for real-estate construction project.

> To thoroughly understand the manpower planning and deployment practices for various building construction projects.

- To analyze and classify manpower demand at various categories.

- To relate project cost and the manpower required and thus forecasting the required manpower for the particular project.

The model was developed based upon data collected from construction projects which were executed in India by using multiple regression method. This paper presents above said model which project managers can use for estimating manpower requirements for construction projects. This paper is organized in four sections. Following this introduction a review of manpower forecasting methods follows. Third section of this paper discusses data attributes and data collection methods used to develop model followed by result analysis and developed model. Finally conclusion from study is presented.

\section{Literature review}

Manpower forecasting is needed mainly to show expected demand of each type of manpower on construction project sites. Since 1960's number of researchers have shown intense interest in this topic. The work in $20^{\text {th }}$ and $21^{\text {st }}$ century is notable as many countries have recognized the importance of forecasting and applied various forecasting methodologies to determine the future training needs (James Wong 2004). This section of paper critically reviews these forecasting methodologies which have been developed and used earlier for demand forecasting at project level.

N K Kwak et al (1977) developed a stochastic model for short term demand forecasting of manpower requirements for a particular functional skill group. Bayesian decision analysis was used to produce a composite forecast of total skill group manpower demand. This model is adaptable to any organizations in which the demand for services from skill group is derived from several projects or activities. In the United States, Georgia Department of Transportation (1993) developed a system for predicting construction engineering manpower system for Georgia Department of Transportation. This system is able to estimate number of employees and engineers required for different construction projects based upon construction dollars. K R Persad et al (1995) using simple regression and multiple regression techniques developed a forecasting model to forecast engineering manpower requirements in terms of engineering man hours as well as engineering cost. They concluded from their study that project construction cost and project type are excellent predictors of engineering manpower requirements. Bell $L C$ et al (2003) developed a model to forecast manpower requirements as a function of project types and cost for selected employee classification. Using data from 130 completed highway construction projects and over 11000 employee payroll entries, regression analysis plots were generated to predict overall manpower requirements for project of given type and cost. 


\begin{tabular}{|c|c|c|c|c|}
\hline \multirow{2}{*}{ Model } & Unstandardized Coefficients & $\begin{array}{c}\text { Standardized } \\
\text { Coefficients }\end{array}$ & Beta \\
\cline { 2 - 4 } (Constant) & B & Std. Error & 3.621 \\
\hline $\begin{array}{c}\text { cost of project in Rs. } \\
\text { Crore }\end{array}$ & 9.276 & 2.562 & .011 \\
\hline
\end{tabular}

a. Dependent Variable: Engineers

Engineers $=9.276+0.026 *$ cost of project

Table 1. Coefficients for Engineers

\begin{tabular}{|c|c|c|c|c|c|}
\hline \multirow{2}{*}{ Model } & \multicolumn{2}{|c|}{ Unstandardized Coefficients } & \multirow{2}{*}{$\begin{array}{c}\text { Standardized } \\
\text { Coefficients } \\
\text { Beta }\end{array}$} & \multirow{2}{*}{$\mathrm{t}$} & \multirow{2}{*}{ Sig. } \\
\hline & B & Std. Error & & & \\
\hline (Constant) & -.470 & .563 & & -.835 & .436 \\
\hline $\begin{array}{c}\text { cost of project in Rs. } \\
\text { Crore }\end{array}$ & .055 & .008 & .938 & 6.628 & .001 \\
\hline
\end{tabular}

a. Dependent Variable: consultants Consultants $=-0.470+0.055$ * cost of project

Table 2. Coefficients for Consultants

\begin{tabular}{|c|c|c|c|c|c|}
\hline \multirow{2}{*}{ Model } & \multicolumn{2}{|c|}{ Unstandardized Coefficients } & \multirow{2}{*}{$\begin{array}{c}\text { Standardized } \\
\text { Coefficients } \\
\text { Beta }\end{array}$} & \multirow{2}{*}{$\mathrm{t}$} & \multirow{2}{*}{ Sig. } \\
\hline & B & Std. Error & & & \\
\hline (Constant) & 2.332 & .411 & & 5.676 & .001 \\
\hline $\begin{array}{c}\text { cost of project in Rs. } \\
\text { Crore }\end{array}$ & .038 & .006 & .931 & 6.226 & .001 \\
\hline
\end{tabular}

a. Dependent Variable: administrators Administrators $=\mathbf{2 . 3 3 2}+\mathbf{0 . 0 3 8}$ * cost of project

Table 3. Coefficients for administrators

\begin{tabular}{|c|c|c|c|c|c|}
\hline \multirow{2}{*}{ Model } & \multicolumn{2}{|c|}{ Unstandardized Coefficients } & $\begin{array}{c}\text { Standardized } \\
\text { Coefficients }\end{array}$ & \multirow{2}{*}{$\mathrm{t}$} & \multirow{2}{*}{ Sig. } \\
\hline & B & Std. Error & Beta & & \\
\hline (Constant) & 154.454 & 22.282 & & 6.932 & .000 \\
\hline $\begin{array}{c}\text { cost of project in Rs. } \\
\text { Crore }\end{array}$ & 2.376 & $\cdot 329$ & .947 & 7.212 & .000 \\
\hline
\end{tabular}

a. Dependent Variable: shopfloor

Table 4. Coefficients for Shop Floor level

Chan et al (2003) using simple regression analysis developed a model to estimate total labour required for any given type of project using labour demand cost relationship. Chan et al (2006) developed a forecasting model on the basis of labour multipliers approach by driving the relationship between number of workers required and project

\section{Shop Floor $=154.454+2.376$ * cost of project}

expenditure in the given project duration. The model can also be used to predict the number of jobs created for a given level of investment. The government can apply this model to check and compare which project type will generate most jobs before committing public money. Wong et al (2008) developed 11 manpower demand forecasting models for total project labour and ten essential trades by using multiple regressions. They concluded from their study that project labour demand depends not only on a single factor, but a cluster of variables related to the project characteristics, including construction cost, project complexity attributes, physical site conditions and project type. 


\begin{tabular}{|c|c|c|c|c|}
\hline Model & $R$ & R Square & Adjusted R Square & Std. Error of the Estimate \\
\hline 1 & $.986 a$ & .973 & .937 & 8.018 \\
\hline
\end{tabular}

a. Predictors: (Constant), shopfloor, engineers, consultants, administrative

Table 5. Model Summary

\begin{tabular}{|c|c|c|c|c|c|}
\hline Model & Sum of Squares & Df & Mean Square & F & 27.202 \\
\hline Regression & 6995.013 & 4 & 1748.753 & 611 \\
\hline Residual & 192.862 & 3 & 64.287 & \\
\hline Total & 7187.875 & 7 & \\
\hline
\end{tabular}

a. Predictors: (Constant), shopfloor, engineers, consultants, administrative

b. Dependent Variable: cost of project in Rs. Crore

Table 6. ANOVA

\begin{tabular}{|c|c|c|c|c|c|}
\hline \multirow{2}{*}{ Model } & \multicolumn{2}{|c|}{ Un standardized Coefficients } & $\begin{array}{c}\text { Standardized } \\
\text { Coefficients }\end{array}$ & T \\
\cline { 2 - 6 } & B & Std. Error & Beta & .123 \\
\hline (Constant) & -41.764 & 19.616 & & -2.129 & .630 \\
\hline engineers & -.843 & 1.578 & -.081 & -.535 & .643 \\
\hline consultants & 3.027 & 5.901 & .178 & .513 & .356 \\
\hline administrative & 9.557 & 8.773 & .388 & 1.089 & .084 \\
\hline shopfloor & .197 & .077 & .493 & 2.555 & .084 \\
\hline
\end{tabular}

a. Dependent Variable: cost of project in Rs. Crore

Table 7. Coefficients for all independent variables

\section{Data collection and analysis}

residential/commercial building constructions during 2005-2012 are considered for developing this estimation model. Manpower requirement varies from building project to infrastructure project construction and hence data collection was done only from residential or commercial building projects. Questionnaire survey is used for collection of data and data regarding manpower utilized and total project costs were collected from selected construction project sites. Total manpower used in all projects was categorized in to four categories as Engineers, Consultants, Administrators and Shop Floor level.
Collected data about project cost and manpower used was used to develop regression models for all four categories of manpower by using statistical software SPSS (Statistical Package for the Social Sciences). The outputs generated by regression analysis for all four categories of manpower are presented respectively in Table 1 , Table 2, Table 3 and Table 4. In these tables, the values in column " $B$ " are the coefficients of the regression equation and accordingly the regression models for various categories of manpower are formulated.

Table 5 shows the Model summary in which Correlation coefficient $R=.986$, indicates that entire model is highly correlated with cost of project. Total variation defined by all the variables is $97.3 \%$ i.e. the project is feasible from data point of view with only $2.7 \%$ loss of data. As per Statistics, if the value of $R$ $=1$ then the respective model is highly correlated and $R=-1$ then the model is highly correlated in reverse fashion i.e. no positive relation can be obtain. In this case, $R=0.986$ which is nearly equals to 1 , hence the correlation can be found out with very less amount of loss in data. The ANOVA table tests the acceptability of the model from a statistical perspective (Table 6). The Regression row displays information 


\begin{tabular}{|c|c|c|c|}
\hline Manpower categories & Actual data collected from site & $\begin{array}{l}\text { Analyzed data based on } \\
\text { regression equations obtained }\end{array}$ & Difference \\
\hline Engineers & 15 & 11.85 & 3.15 \\
\hline Consultants & 4 & 4.97 & 0.97 \\
\hline Administrators & 6 & 6.09 & 0.09 \\
\hline Shop floor & 397 & 389.67 & 7.33 \\
\hline
\end{tabular}

Table 8. Comparative analysis between actual project vs models

about the variation accounted for by the model. The Residual row displays information about the variation that is not accounted for by the model. The regression and residual sums of squares are not equal, i.e. regression sum of squares is greater than residual sum of squares which indicates that about entire of the variation is explained by the model. The significance value of the F statistic is less than 0.05 (value $=$ 0.011), which means that the variation explained by the model is not due to chance and hence acceptable.

Table 7 gives the regression equation coefficients in consideration with all the independent variables (Engineers, Consultants, Administrators and Shop floor labor) and dependent variable (Cost of project).

\section{General Regression Equation:}

$\mathrm{Y}=-41.76-0.843 \mathrm{X}_{1}+\mathbf{3 . 0 2 7} \mathrm{X}_{2}+9.557$ $X_{3}+0.197 X_{4}$

The beta coefficient tells that how strongly the independent variable is associated with the dependent variable.

Above table indicates that independent variable Shop Floor is highly associated (Beta Coefficient .493) with dependent variable Cost of Project.

P-Significance value .011 means significance i.e. it is the significance of model.

Negative sign for the coefficient of Engineers indicates uncertainty in the data available.

\section{Validity of the models}

Validity of models was tested by comparing predicted values with actual values for construction project site which is located in Mumbai. Forecasting performance of all four models is as shown in Table 8.

The results of the validation confirm that the forecasting models are predicting manpower demand with very less amount of deviation.

\section{Limitations of the models}

Although models predict manpower demand for construction projects, it is acknowledged that the models are subject to following limitations:

The study was limited to only residential or commercial building construction projects. As project cost vary from structure to structure, above regression models are useful to calculate manpower demand only for similar kind of projects which involve similar kind of activities.

- Developed regression models give only approximate manpower demand for only four categories such as Engineers, Consultants, Administrators and Shop Floor level.

The results were derived from a sample of selected projects only, which may not be sufficient to develop regression models for all projects.

- Labour demand and project cost of construction projects depend upon construction methods and technology, construction materials used. It is advisable to update models taking into consideration the change in construction methods, technology and construction materials to get more accuracy.

\section{Conclusion}

Review of literature concluded that project cost is one of the major factors which affect project manpower demand. Hence project cost and manpower data from selected residential/ commercial building projects were collected to develop regression models using multiple regression analysis. By using this data manpower forecasting models were created for four categories such as Engineers, Consultants, Administrators and Shop Floor level. The models were then verified by comparing predicted values with actual values for one building construction project. Results of validity test indicate that the developed models predict manpower demand for construction project with minimum deviation. Contracting agencies can use these models to estimate manpower requirement for effective personals deployments for execution of a new construction project. This facilitates better manpower planning and budgeting for projects and will help to curb delays in completion of construction work. 


\section{References}

Albert P C Chan, Y H Chiang, Stephen W K Mak, Lennon H T Choy and James M WM Wong (2006) "Forecasting the demand for construction skills in Hong Kong", Construction Innovation, PP $3-19$.

Bell L C and Brandenburg S G (2003) “Forecasting construction staffing for transportation agencies", Journal of Management in Engineering, Vol 19, No.3, PP 116- 120.

Chan, A. P. C., Wong, J. M. W., and Chiang, Y. H. (2003). “Modeling labor demand at project level-An empirical study in Hong Kong”, Journal of Engineering, Design and Technology, Vol 1, No 2, PP 135-150.

G Coates, A H B Duffy, W Hills, and R I Whitfield (2007) “A preliminary approach for modeling and planning the composition of engineering project teams", Proceedings IMechE Vol 221 Part B: Journal of Engineering Manufacture, PP 1255-1264.

Georgia Department of Transportation, Technical report on (1993) “Development of a Construction engineering manpower system for Georgia DOT".

Indian Standard IS: 7272 (Part-I) - 1974, Recommendation for labour output constants for building work, Indian Standards Institution, New Delhi.

James M. W. Wong, Albert P. C. Chan, and Y. H. Chiang (2004) "A critical review of forecasting models to predict manpower demand", The Australian Journal of Construction Economics and Building, Vol 4, No. 2, PP 43-55.

James M. W. Wong; Albert P. C. Chan; and Y. H. Chiang (2008) “Modeling and Forecasting Construction Labor Demand: Multivariate Analysis", Journal of Construction Engineering and Management Vol 134, No 9, PP 664- 672.

Khali R Persad, J T O'Connor, and Koshy Varghese (1995) “Forecasting engineering manpower requirements for highway preconstruction activities", Journal of Management in Engineering, Vol 11, No.3, PP 41- 47.

N K Kwak, Walter a Garrett, and Sam Barone (1977) “A stochastic model for demand forecasting for technical manpower planning”, Management Science, Vol 23, No 10 PP 1089- 1097 